\title{
TINJAUAN YURIDIS TERHADAP PELAKU TINDAK PIDANA PEMBUNUHAN BAYI (STUDI KASUS PUTUSAN NOMOR 1123/Pid.Sus/2018/PN Dps
}

\author{
Desak Ketut Parwati, I Wayan Rideng, Ni Made Sukaryati Karma \\ Fakultas Hukum, Universitas Warmadewa, Denpasar-Bali, Indonesia \\ desakketutparwati45@gmail.com, wayanrideng1965@gmail.com, sukariati64@gmail.com
}

\begin{abstract}
Abstrak
Perlindungan terhadap bayi sudah dimulai sejak anak tersebut berada dalam kandungan ibunya. Sesuai dengan pasal 2 Burgerlijk Wetboek bahwa seorang anak yang masih dalam kandungan ibunya dianggap sebagai subyek hukum sepanjang kepentingan anak itu dikehendaki. Namun saat ini kasus pembunuhan terhadap bayi sering terjadi maka dalam hal ini diperlukannya perlindungan hukum. Tujuan penelitian ini untuk menganalisa pengaturan sanksi pidana bagi pelaku tindak pidana pembunuhan bayi serta pertimbangan hakim terhadap pelaku tindak pidana pembunuhan bayi. Tipe Penelitian yang digunakan dalam penulisan ini adalah tipe penelitian Hukum Normatif dengan pendekatan perundang-undangan dan konseptual. Adapun sumber bahan hukum yang digunakan yaitu bahan hukum primer dan sekunder. Setelah data dikumpulkan, kemudian data dianalisis secara sistematis. Hasil penelitian mengungkapkan bahwa pengaturan sanksi bagi pelaku tindak pidana pembunuhan bayi sebagimana diatur dalam Undang- Undang Nomor 35 Tahun 2014 tentang Perlindungan Anak. Pertimbangan hakim dalam menjatuhkan putusan terhadap pelaku tindak pidana pembunuhan bayi yang mengakibatkan kematian, meliputi; keterangan saksi yang telah diajukan oleh penuntut umum di depan persidangan, berdasarkan keterangan terdakwa di persidangan dan berdasarkan unsur-unsur dari tindak pidana yang didakwakan oleh penuntut umum dalam dakwaan tunggal telah terpenuhi.
\end{abstract}

Kata Kunci: Pembunuhan Bayi, Tindak Pidana, Tinjauan Yuridis

\begin{abstract}
Protection for babies has started since in the womb. In accordance with article 2 Burgerlijk Wetboek that a child who is still in his mother's womb is considered a legal subject as long as the interests of the child are desired. However, nowadays cases of infanticide often occur, so in this case legal protection is needed. The purpose of this research is to analyze the regulation of criminal sanctions for the perpetrators of the crime of infanticide and the judge's consideration of the perpetrators of the crime of infanticide. The type of research used in this paper is a normative law research type with a statutory and conceptual approach. The sources of legal materials used are primary and secondary legal materials. After the data is collected, then the data is analyzed systematically. The results of the research reveal that the setting of sanctions for perpetrators of the crime of infanticide is as regulated in Law Number 35 of 2014 concerning Child Protection. The judge's considerations in making a decision against the perpetrators of the crime of infanticide which resulted in death, include; witness statements that have been submitted by the public prosecutor before the trial, based on the testimony of the defendant at the trial and based on the elements of the crime charged by the public prosecutor in the single indictment have been fulfilled.
\end{abstract}

Keywords: Infant Murder, Crime, Juridical Review

\section{PENDAHULUAN}

Negara Indonesia menurut Undang-Undang Dasar Negara Republik Indonesia 1945 adalah Negara hukum dalam arti yang luas, yang menjamin hak-hak dan kewajiban hak asasi manusia, memajukan kesejahteraan rakyat dan keadilan social berdasarkan Pancasila (Nawawi, 2008). Buah hati ialah karunia yang diberikan oleh tuhan tidak terhitung dari Tuhan Yang Maha Esa. generasi ialah angkatan pelanjut yang dimana bisa melindungi serempak dengan menaikkan derajat keberadaan orang tersebut. Anak adalah seseorang yang belum berusia 18 (delapan belas) tahun, termasuk anak yang masih dalam kandungan. Dengan karena itu menjaga atas anak justru mulai sedari bayi itu ada ditengah rahim ibundanya. Pasal 2 Burgerlijk Wetboek (BW) menerangkan: "seorang anak yang masih dalam kandungan ibunya dianggap sebagai subyek hukum sepanjang kepentingan si anak itu menghendakinya". 
Dalam ketentuan Undang-Undang Dasar Negara Republik Indonesia Tahun 1945, Pasal 28B ayat (2) mengatakan: "setiap anak yang lahir baik itu dari perkawinan yang sah ataupun tidak sah maka ia berhak untuk hidup dengan memberikan kebutuhan primer, sekunder dan tersier; tumbuh; mengembangkan dirinya dengan memberikan pendidikan dan melindungi diri atau dilindungi oleh keluarganya serta negara dari kejahatan berupa kekerasan dan diskriminasi baik itu dilakukan oleh keluarganya sendiri atau oleh orang lain.

Menurut para sarjana di Indonesia mengistilahkan strafbaareit itu dalam arti yang berbeda menurut, Moeljatno menggunakan istilah perbuatan pidana, yaitu "perbuatan yang dilarang oleh suatu aturan hukum, larangan mana disertai ancaman sanksi yang berupa pidana tertentu, bagi barang siapa larangan tersebut (C.S.T. \& Kansil, 2004). Anak wajib dilindungi agar mereka tidak menjadi korban tindakan siapa saja (individu atau kelompok, organisasi swasta maupun pemerintah) baik secara langsung maupun tidak langsung (Gosita, 1989).

Kasus pembunuhan terhadap bayi kembar yang dilakukan pada tanggal 12 Juli 2018 oleh terdakwa Dafriana Wulansari alias Lani berusia 20 tahun, perbuatan tersebut dilakukan sekitar pukul 02.00 wita, di tempat kos pacar terdakwa yang berstatus sebagai saksi, Fenantianus Karitas Redento alias Fenan. Yakni di Jalan Ratna, Gang Werkudara, Nomor 6 Denpasar Timur. Kasus pembunuhan bayi yang baru saja dihadirkan ke dunia sangat condong dalam kasus kebatinan, memiliki desakan ataupun ganjalan otak serebral yang mengampu seorang ibundanya kepada bayi yang dihadirkan ke dunia, serta kasus latar belakang kemasyarakatan. kegiatan untuk membendung serta bila perlu dalam mengenai bantuan dampat takut bagi pelaksana delik menghilangkan nyawa bayi berikut ialah dengan jalan membentuk suatu norma hukum pidana yang spesifik, sampai-sampai mendapatkan terwujudnya suatu ketegasan hukum yang dikemudian hari akan berakhir pada kepastian hukum (S, 2002).

Pada dasarnya pembunuhan merupakan bentuk kejahatan bertentangan dengan norma-norma dan hukum yang ada dalam masyarakat yaitu norma agama dan hukum adat istiadat, sekaligus bertentangan dengan norma ketentuan hukum pidana dan melanggar hak asasi manusia yaitu hak untuk hidup (Simbolon et al., 2019). Menghilangkan nyawa orang lain dengan unsur kesengajaan telah ditetapkan dalam kitab Undang-undang Hukum Pidana (KHUP) juga disebut sebagai suatu pembunuhan, Tindak pidana pembunuhan atau kejahatan terhadap nyawa (misdrijven tegen het leven) adalah berupa penyerangan terhadap nyawa orang lain (Mangare, 2016). Dalam hal ini dapat dikatakan bahwa tindak pidana pembunuhan sebagai delik material bila delik tersebut selesai dilakukan oleh pelakunya dengan timbulnya akibat yang dilarang atau yang tidak dikehendaki oleh Undang-undang (Halawa et al., 2020).

Berdasarkan uraian diatas, maka dirumuskannya tujuan penelitian ini untuk menganalisa pengaturan sanksi pidana bagi pelaku tindak pidana pembunuhan bayi serta pertimbangan hakim terhadap pelaku tindak pidana pembunuhan bayi.

\section{METODE PENELITIAN}

Tipe Penelitian yang digunakan dalam penulisan ini adalah tipe penelitian Hukum Normatif oleh karenanya pengkajian dilakukan melalui sumber bahan hukum primer yaitu: berupa bahan-bahan hukum dan pendekatan masalahnya adalah pendekatan Perundang-undangan, (statue approach) yang berlaku dan berkaitan dengan permasalahan secara konseptual (conteptual approach) yaitu, menganalisis permasalahan yang akan dibahas melalui konsep-konsep hukum yang diambil dari bukubuku dan literatur-literatur yang ada relevansinya dengan permasalahan, serta menggunakan pendekatan kasus. Adapun sumber bahan hukum yang digunakan yaitu bahan hukum primer yaitu bahan hukum yang diperoleh dari Peraturan Perundang-undangan, subjek kaidah sekunder ialah subjek kaidah yang selaras dengan subjek kaidah primer serta bisa menolong untuk menganalisis, mengetahui bahkan mengartikan subjek kaidah sekunder, antara lain: literatur-literatur, jurnal ilmu hukum, produk konferensi alat cap bahkan barang modern serta subjek kaidah tersier ialah subjek kaidah yang bisa mempersembahkan fakta, bukti, dan deskripsi kepada subjek kaidah primer bahkan sekunder, contohnya: ensiklopedia dan lain sebagainya. Adapun teknik pengumpulan bahan hukum yang dilakukan adalah dengan teknik pencatatan artinya bahan hukum yang dikumpulkan diklasifikasi sesuai dengan jenis bahan hukum yang digunakan seperti: teori-teori hukum, jurnal hukum dan pendangan-pandangan ahli hukum, demikian juga dengan perundang-undangan yang terkait, selanjutnya dibaca dikutip, diringkas dan diberikan ulasan sesuai dengan pokok permasalahan yang dibahas. Analisis Bahan Hukum dari bahan-bahan hukum yang dikumpulkan, baik bahan hukum 
primer maupun bahan hukum sekunder kemudian diolah dan dianalisis untuk memperoleh suatu kebenaran dan berusaha untuk memahami kebenaran tersebut. Bahan hukum yang sudah terkumpul dan telah dikelompokan serta diolah dan dianalisis dengan metode interpretasi hukum secara sistematis, diberikan penafsiran dengan argumentasi untuk mendapatkan suatu simpulan yang bersifat tepat, benar, dan ilmiah, serta logis sebagai hasil akhir penelitian ini.

\section{HASIL DAN PEMBAHASAN}

\section{Pengaturan Sanksi Pidana bagi Pelaku Tindak Pidana Pembunuhan Bayi}

Denda kriminal ialah merupakan bentuk denda yang berwatak kesedihan yang mengintimidasi atau diberikan kepada suatu kegiatan atau aktor aksi kriminal ataupun delik yang bisa memprovokasi atau bahkan membinasakan keperluan kaidah (Chazawawi, 2002). Adapun Undang-Undang yang mengatur sanksi pidana untuk pembunuhan terhadap bayi yaitu Pasal 341 KUHP dan Pasal 342 KUHP yang rumusanya: "Seorang ibu yang karena takut akan ketahuan melahirkan bayi pada saat bayi dilahirkan atau tidak lama kemudian, dengan sengaja menghilangkan nyawa anaknya dipidana karena membunuh banyinya sendiri dengan pidana penjara paling lama 7 tahun." Dalam UndangUndang Nomor 35 Tahun 2014 tentang Perlindungan Anak Pasal 80 ayat 3 menyatakan "Dalam hal Anak sebagaimana dimaksud pada ayat (2) mati, maka pelaku dipidana dengan pidana penjara paling lama 15 (lima belas) tahun dan/atau denda paling banyak Rp. 3.000.000.000,00 (tiga miliar rupiah)".

Berdasarkan fakta-fakta yang terungkap di persidangan tahap pembuktian terhadap unsur dakwaan, maka menurut jaksa penuntut umum menggunakan dakwaan tunggal yang didakwaan kepada terdakwa tersebut dinyatakan terbukti yaitu Pasal 76 C No. Pasal 80 ayat (3) dan ayat (4) Undang-Undang Nomor 35 Tahun 2014 mengenai pemeliharaan bocah, dalam unit-unit sebagai berikut

a) Semua individu

b) Meletakkan, membebaskan, melaksanakan, menyelenggarakan, atau bahkan ikut serta melaksanakan suatu kekejaman fisik kepada bayi yang bisa memicu kematian.

c) Dilakukan oleh orang tuanya.

Beralaskan unit di atas oleh sebab itu penulis membuat kesimpulan dimana semua unit-unit oleh dugaan sudah terwujud serta sudah memastikan yang mulia hakim dalam akidah bahwasannya terduga sudah ketahuan salah dengan melampaui Pasal $76 \mathrm{C}$ No. pasal 80 ayat (3) dan ayat (4) Undang-Undang Nomor 35 Tahun 2014 Tentang Perlindungan Anak dan menjatuhkan sanksi pemidaan pada Defriani Wulansari.

Adanya tujuan pidana guna untuk menentramkan masyarakat yang gelisah akibat suatu kejahatan. Serta mencegah kejahatan yang telah terjadi pada masyarakat yang dapat dibedakan atas pencegahan umum (generale preventie) dan pencegahan khusus (speciale preventie) (Hutahaean, 2013). Berdasarkan obyek atau korban (kepentingan hukum yang dilindungi) kejahatan terhadap nyawa terhadap nyawa bayi pada saat dilahirkan atau sesaat/tidak lama setelah dilahirkan, telah diatur dalam Pasal 341, 342, dan 343 KUHP (Mentari, 2020).

\section{Pertimbangan Hakim Terhadap Pelaku Tindak Pidana Pembunuhan Bayi}

Pertimbangan Majelis Hakim Pengadilan Negeri Denpasar dengan Putusan Nomor 1123/Pid.Sus/2018/PN Dps yang mengawasi serta memeriksa ihwal berikut sesudah memperhitungkan pembuktian para saksi-saksi, maklumat terduga, dalil, serta visum et repertum dapat dipenuhi unit-unit kaidah sebagai berikut.

a) Maka di hari Rabu 11 Juli 2018 Terdakwa dijemput oleh Fenan untuk diajak menginap di kamar kos Fenan di Jalan Ratna Gang Werkudara Nomor 6 Denpasar.

b) Bahwa di kamar kos Fenan pada hari Kamis dini hari jam 02.00 wita terdakwa merasakan sakit pada perutnya dan pergi ke ruangan mandi dan selanjutnya melahirkan anak yang pertama dari Rahim Terdakwa dan ketika anak itu merintih, terduga lantas mencekik leher anak itu dengan menggunakan tangan kiri sehingga bayi tersebut berhenti menangis lalu Terdakwa mengambil pisau dapur yang bisa dijangkau oleh tangan kanan Terdakwa lalu Terdakwa menusuk perut dan leher bayi tersebut masing-masing satu kali, kemudian terdakwa membungkus bayi tersebut dengan kain warna hitam setelah itu dibungku laku dengan menggunakan kantong plastik warna putih dan meletakkan bayi tersebut, kemudian Terdakwa melahirkan bayi yang kedua dan langsung menangis, kemudian Terdakwa langsung 
mncekik leher bayi yang kedua tersebut dengan tangan kiri hingga berhenti menangis lalu dengan pisau dapur yang sama Terdakwa lalu menusuk perut dan mulut bayu tersebut sebanyak satu kali.

c) Bahwa Terdakwa lalu membungkus bayi kedua dengan menggunakan celana dalam merah dan memasukkan bayi tersebut ke dalam kantong plastic warna hitam, seteah itu Terdakwa membersihkan kamar mandi dan menyiram darah yang tercecer di lantai kamar mandi dan membershikan pisau yang Terdakwa gunakan untuk menusuk kedua bayu tersebut dari noda darah.

d) Bahwa setelah selesai membershikan kamar mandi dan pisau Terdakwa lalu mengenakan kembali celana Terdakwa dan keluar dari kamar kos dan tetangga sebelah kamar menanyakan kepada Terdakwa apaah ada mendengar suara tangisan bayi namun Terdakwa mengatakan tidak ada;

e) Bahwa Terdakwa lalu mengambil kantong plastik yang berisi dua orang bayi dari kamar mandi dan memasukkan bayi tersebut ke dalam kantong warna coklat lalu dimasukkan ke dalam tong beras yang ada di dapur;

f) Bahwa ketika Fenan melihat ada bercak darah di kamar mandi dan menanyakan hal tersebut, Terdakwa mengatakan kalau darah tersebut adalah darah mensturasi Terdakwa;

g) Bahwa ketika Fenan pergi membelikan masker, Terdakwa mengambil kedua bayi yang sebelumnya disimpan di tong beras lalu dibawa keluar kamar kos dan meletakkannya di celah samping kamar kos kemudian Terdakwa bersama Fenan pegi ke tempat kos Terdakwa di Jimbaran;

h) Bahwa Terdakwa mencekik dan menusuk bayi yang dilahirkan oleh Terdakwa karena Terdakwa merasa panic dan ketakutan jika suawa bayi tersebut didengar oleh orang lain dan akan ketahuan bahwa Terdakwa telah melahirkan;

i) Bahwa Terdakwa berpacaran dengan FENANSIUS K. REDENTE alias FENAN sejak bulan Juni 2018;

j) Bahwa Terdakwa sering menginap dan berhubungan badan dengan Fenan di kamar kos Fenan di Jl. Ratna Gang Werkudara No. 6 Denpasar;

k) Bahwa saat berpacaran dengan Fenan, Terdakwa sudah hamil yaitu hasil berhubungan dengan pacar sebelumnya bernama JJ, tetapi JJ sudah menghilang sejak mengetahui Terdakwa hamil;

1) Bahwa Fenan tidak mengetahui bahwa Terdakwa hamil karena Terdakwa selalu beralasan sedang datang bulan;

beralaskan unit-unit kaidah dalam perundingan di atas, yang mulia hakim mengenai memutuskan bisa atau tidak individu ketahuan berbuat salah serta bisa dihukum, oleh sebab itu kesemua oleh unit-unit yang disangkakan kepada JPU terhadapnya harus boleh dijelaskan dan terlaksana semuanya. Terdapat bagian yang dijadikan bahan-bahan evaluasi yang digunakan untuk yang mulia hakim didalam menjatuhkan perkara Putusan Nomor : 1123/Pid.Sus/2018/PN Dps yang beralaskan pada unit-unit yang dimana didalam suatu pengadilan serta melalui keseimbangan yang mulia hakim menyorot kepada pasal-pasal yang berselaraskan dengan delik yang diperbuat.

Terdapat hal yang membuat evaluasi yang mulia hakim dalam memberikan putusan kriminal kepada terduga diantaranya:

a) Menimbang, bahwa terhadap dakawaan Penuntut Umum tersebut Terdakwa dan Penasehat Hukum Terdakwa menyatakan tidak mengajukan keberatan/eksepsi.

b) Menimbang, bahwa untuk membuktikan dakwaannya Penuntut Umum telah mengajukan saksi-saksi.

c) Menimbang, maka setelahnya Yang Mulia Hakim akan memperhitungkan apakah beralaskan bukti-bukti kaidah di atas, terduga bisa dinyatakan sudah membuat suatu delik yang sangkakan terhadapnya;

d) Menimbang, maka terduga sudah disangkakan dengan PU dengan disangkakan sendiri sebagai halnya yang tertera dalam ketentuan pasal 76 C No. pasal 80 ayat (3) dan ayat (4) Undang-Undang Republik Indonesia Nomor 35 Tahun 2014 tentang perubahan atas UndangUndang Republik Indonesia Nomor 23 Tahun 2002, yang unsur-unsurnya:

1. Setiap Orang

2. Menempatkan, membiarkan, melakukan, menyuruh melakukan, atau turut serta melakukan kekerasan terhadap Anak yang mengakibatkan mati; 
3. Dilakukan oleh orang tuanya;

Kesatu, Unsur setiap orang:

a) Menimbang, bahwa unsur setiap orang dalam perkara ini adalah menunjuk kepada subjek hukum manusia sebagai pendukung hak dan kewajiban yaitu menunjuk kepada orang yang bernama DAFRIANA WULANSARI Alias LANI dan di dalam proses pemeriksaan, terdakwa telah membenarkan identitas yang bersangkutan sesuai dengan identitas yang tertera di dalam surat dakwaan Penuntut Umum;

b) Menimbang, bahwa oleh karena itu benar bahwa yang hadir dipersidangan sebagai Terdakwa adalah DAFRIANA WULANSARI Alias LANI sebagaimana dimaksud oleh Penuntut Umum dalam surat dakwaannya, dan Terdakwa adalah orang cakap dan mampu untuk bertanggung jawab maka Majelis Hakim menilai unsur setiap orang terpenuhi.

Kedua, Unsur meletakkan, membebaskan, melaksanakan, mmerintahkan melaksanakan, atau bahkan ikut serta melaksanakan kezaliman kepada bayi yang menimbulkan kematian:

a) Menimbang, bahwa yang dimaksud dengan kekerasan adalah setiap perbuatan terhadap anak yang berakibat timbulnya kesengsaraan atau penderitaan secara fisik, psikis, seksual, dan/atau penelantaran, termasuuk ancaman untuk melakukan perbuatan, pemaksaan, atau perampasan kemerdekaan secara melawan hukum;

b) Menimbang, bahwa yang dimaksud dengan anak dalam pasal 1 butir 1 Undang-Undang Nomor 35 Tahun 2014 tentang perubahan atas Undang-Undang Nomor 23 Tahun 2002 adalah seseorang yang belum berusia 18 tahun, termasuk anak yang masih dalam kandungan;

c) Menimbang, bahwa berdasarkan fakta-fakta yang terungkap di persidangan telah terungkap bahwa pada hari Kamis jam 02.00 wita di kamar kos di Jalan Ratna Gang Werkudara Nomor 6 Denpasar, Terdakwa merasakan sakit pada perutnya dan pergi ke ruangan mandi dan setelahnya mengeluarkan anak yang petama dari Rahim Terdakwa dan ketika anak itu merintih, terduga lantas mencekik leher anak itu dengan menggunakan tangan kiri sehingga bayi tersebut berhenti menangis lalu Terdaka mengambil pisau dapur yang bisa dijangkau oleh tangan kanan Terdakwa lalu menusuk perut dan leher bayi tersebut masing-masing satu kali, kemudian Terdakwa membungkus bayi tersebut dengan kain warna hitam setelah itu dibungkus lagi dengan menggunakan kantong plastic warna putih dan meletakkan bayi tersebut. Kemudian Terdakwa melahirkan bayi yang kedua yang langsung menangis kemudian Terdakwa langsung mencekik leher bayi yang kedua tersebut dengan tangan kiri hingga berhenti menangis lalu dengan pisau dapur yang sama Terdaakwa lalu menusuk perut dan mulut bayi tersebut sebanyak satu kali;

d) Menimbang, bahwa akibat perbuatan Terdakwa tersebut dua bayi yang idlahirkan oleh Terdakwa mengalami kematian, sebagaimana dituangkan di dalam Visum Et Repertum Nomor: YR.02.03/XIV.4.4.7/346/2018 dan Visum Et Repertum Nomor: YR.02.03/XIV.4.4.7/347/2018

e) Menimbang, bahwa berdasarkan pertimbangan-pertimbangan di atas maka unsur melakukan kekerasan terhadap anak yang mengakibatkan mati telah terpenuhi;

Ketiga, Unsur dilakukan oleh orang tuanya;

a) Menimbang, bahwa berdasarkan fakta-fakta yang terungkap di persidangan, terdakwa adalah orang tua yaitu ibu yang melahirkan kedua bayi tersebut, dengan demikian unsur ini telah terpenuhi;

b) Menimbang, bahwa oleh karena semua unsur dari Pasal $76 \mathrm{C}$ jo pasal 80 ayat (3) dan ayat (4) Undang-Undang Republik Indonesia Nomor 35 Tahun 2014 mengenai penjagaan bayi telah dipenuhi dalam perbuatan Terdakwa, maka Terdakwa haruslah dinyatakan telah terbukti secara sah dan meyakinkan melakukan tindak pidana sebagaimana didakwakan oleh Penuntut Umum;

c) Menimbang, bahwa ditengah perundingan, Yang Mulia Hakim tidak ditemukannya hal-hal yang dapat menghapuskan pertanggungjawaban pidana, baik sebagai alasan pembenar dan atau alasan pemaaf, maka Terdakwa harus mepertanggungjawabkan perbuatannya;

d) Menimbang, bahwa karena sebab terduga bisa mempertanggung jawabkan perbuatannya, selanjunta harus diejelaskan salah dan diberikan pengadilan;

e) Menimbang, bahwa atas tuntutan Penuntut Umum yang menuntut terdakwa dengan pidana penjara selama 14 (empat belas) tahun, Majelis hakim tidak sependapat dengan lamanya 
pidana tersebut, karena menurut Majelis Hakim, Terdakwa melakukan perbuatan tersebut didorong oleh perasaan panik dan ketakutan karena memiliki anak tanpa pernikahan yang sah;

f) Menimbang, bahwa ditengah kejadian tersebut terhadap terduga sudah deberikan penangkapan dan penahanan yang sah, maka masa penangkapan dan penahanan tersebut harus dikurangkan seluruhnya dari pidana yang dijatuhkan;

g) Menimbang, bahwa karena terduga dipenjara dan penangkapan kepada terduga beralaskan kepada suatu dalil yang jelas oleh sebab itu perlu dipermanenkan supaya terduga tetap ada ditengah penjara;

h) Menimbang, bahwa oleh dijatuhkannya suatu putusan pengadilan kepada diri terduga, oleh sebab itu didesak untuk memperhitungkan terlebih dahulu sebelumnya dalam faktor yang memojokkan dan memudahkan

faktor yang memojokkan:

1. Kegiatan terduga membuat kegaduhan kepada penduduk sekitar

Keadaan yang meringankan:

1. Terdakwa mengakui terus terang perbuatannya sehingga memperlancar persidangan

2. Terdakwa merasa sangat bersalah dan menyesali perbuatannya

3. Terdaakwa masih sangat muda sehingga diharapkan dapat memperbaiki perilakunya dikemudian hari

4. Terdakwa belum pernah dihukum

Beralaskan penulis bahwasannya unit-unit yang memojokkan terduga yang membuat bahan evaluasi Yang Mulia Hakim sebelum memberikan putusan ditengah dakwaan berikut dengan Nomor 1123/Pid.Sus/2018/PN Dps telah beralaskan oleh perbuatan yang membuat dari delik penghilangan nyawa kepada bayi. Menurut penulis, penting untuk ditelusuri apakah niat untuk membunuh tersebut muncul ketika bayi masih dalam kandungan atau ketika ia mengetahui telah melahirkan bayi tersebut. Meskipun Undang-Undang Nomor 35 Tahun 2014 tidak menjelaskan mengenai waktu munculnya niat membunuh, tetapi jika niat membunuh bayi sudah ada ketika bayi masih dalam kandungan, hal tersebut bisa menjadi pertimbangan untuk memperberat putusan hakim.

Beralaskan definisi evaluasi di atas, maka yang mulia hakim membuat suatu kesimpulan bahwasannya semua unit-unit oleh dugaan JPU sudah tersalurkan serta sudah membuktikan kepada yang mulia hakim pada itikad bahwasannya terduga sudah ketahuan berbuat salah dengan melampaui ketentuan Pasal 76 C No. pasal 80 ayat (3) dan ayat (4) Undang-Undang Republik Indonesia Nomor 35 Tahun 2014 dan menjatuhkan sanksi pemidanaan kepada terdakwa DEFRIANA WULANSARI Alias LANI.

\section{SIMPULAN DAN SARAN}

\section{Simpulan}

Pengaturan sanksi bagi pelaku tindak pidana pembunuhan bayi diatur dalam Pasal 76C No. Pasal 80 ayat (3) dan ayat (4) Undang-Undang Nomor 35 Tahun 2014 mengenai pemeliharaan bayi, dimana terancam pengadilan kurungan paling lamban 15 (lima belas) tahun, tetapi ditengah fatwa yang mulia hakim hanya menjatuhkan kurungan kepada terduga dengan pengadilan kurungan 10 tahun dan pidana denda sebesar Rp. 10.000.000,00. Adapun pertimbangan hakim dalam menjatuhkan putusan terhadap pelaku tindak pidana pembunuhan bayi yang mengakibatkan kematian, meliputi beralaskan dalam informasi dalil yang sudah diberikan untuk PU di hadapan perhimpunan, beralaskan informasi terduga di perundingan; serta beralaskan kepada unit-unit oleh delik yang dalam pengaduan untuk PU dalam tuntutan satu-satunya sudah dipenuhi.

\section{Saran}

Terhadap pembuat Undang-undang, Pemerintah dan Legislatif untuk melakukan revisi/harmonisasi antara Peratutan Perundang-undangan agar terjadi sinkronisasi dan memberikan kepastian bagi pelaksana peneggakan hukum. Kepada masyarakat, para orang tua agar memberi perhatian terhadap anak-anaknya agar tidak menjadi korban yang tidak bertanggungjawab. Sehingga dapat menatap masa depan sesuai dengan cita-citanya.

\section{DAFTAR PUSTAKA}

Chazawawi, A. (2002). Pelajaran Hukum Pidana bagian I. PT Grafindo Persada, Jakarta. 
C.S.T., K., \& Kansil, C. S. T. (2004). Pokok-Pokok Hukum Pidana. Pradnya Paramita, Jakarta.

Gosita, A. (1989). Masalah Perlindungan Anak. Akademi Presindo, Jakarta.

Halawa, M., Munawair, Z., \& Hidayani, S. (2020). Penerapan Hukum Terhadap Tindak Pidana Pembunuhan Dengan Sengaja Merampas Nyawa Orang Lain (Studi Kasus Nomor Putusan 616/Pid.B/2015/PN. Lbp). JUNCTO: Jurnal Ilmiah Hukum, 2(1), 9-15.

Hutahaean, B. (2013). Penerapan Sanksi Pidana bagi Pelaku Tindak Pidana Anak. Jurnal Yudisial, $6(1), 64-79$.

Mangare, P. (2016). Kajian Hukum Tindak Pidana Pembunuhan Anak oleh Ibu Kandungnya (Menurut Pasal 134 KUHP). Jurnal Lex Privatum, 14(2), 82-91.

Mentari, B. M. R. (2020). Saksi Pidana Pembunuhan Dalam Kitab Undang-Undang Hukum Pidana Dengan Hukum Islam. AL-ISHLAH: Jurnal Ilmiah Hukum, 22(1), 1-38.

Nawawi, A. B. (2008). Kumpulan Hasil Seminar Nasional ke-1 s/d ke-VIII, dan Konvensi Hukum Nasional. Pustaka Magister, Semarang.

Simbolon, V. E. B., Simarmata, M., \& Rahmayanti. (2019). Tinjauan Yuridis terhadap Tindak Pidana Pembunuhan Berencana Menggunakan Besi Padat di Medan Tinjauan Kasus Nomor 2305/Pid.B/2017/Pn.Mdn. Jurnal Mercatoria, 12(1), 54-67.

S, R. (2002). Polri Sipil dan Perubahan Sosial di Indonesia. Kompas, Jakarta. 